\title{
HUBUNGAN HIGIENE PERORANGAN DAN PENGGUNAAN ALAT PELINDUNG DIRI DENGAN KSEJADIAN DERMATITIS KONTAK AKIBAT KERJA PADA PEKERJA PENGANGKUT SAMPAH DI DLHK KOTA DENPASAR TAHUN 2020
}

\author{
I Gede Sutha Arta Pramana*, Ni Wayan Arya Utami \\ Program Studi Sarjana Kesehatan Masyarakat, Fakultas Kedokteran Universitas Udayana \\ Alamat: Jalan PB. Sudirman, Denpasar, Bali 80232.
}

\begin{abstract}
ABSTRAK
Tingginya angka kejadian dermatitis kontak pada pekerja pengangkut sampah dikarenakan petugas pengangkut sampah setiap harinya mengalami kontak langsung dengan sampah sebagai agen yang meningkatkan risiko terjadinya dermatitis kontak akibat kerja. Tujuan penelitian ini untuk mengetahui hubungan antara higiene perorangan dan penggunaan alat pelindung diri dengan dermatitis kontak akibat kerja pada pekerja pengangkut sampah di Dinas Lingkungan Hidup dan Kebersihan Kota Denpasar. Penelitian ini bersifat kuantitatif dengan rancangan cross sectional. Sampel penelitian adalah pekerja pengangkut sampah di DLHK Kota Denpasar dengan jumlah sampel minimal 84 responden. Teknik pemilihan sampel dengan simple random sampling. Penelitian dilakukan pada Bulan Maret-Juni tahun 2020. Data dianalisis untuk meneliti hubungan antar variabel yang diuji dengan analisis bivariat. Hasil penelitian menunjukkan terdapat 26,19\% pekerja mengalami dermatitis kontak akibat kerja. Terdapat hubungan yang signifikan antara masa kerja, jam kerja, kebersihan kulit, kebersihan rambut dan kulit kepala, kebersihan kuku, tangan, dan kaki, penggunaan sarung tangan, penggunaan baju dan celana panjang, penggunaan sepatu boot dengan kejadian dermatitis kontak akibat kerja. Sedangkan pada variabel umur, tingkat pendidikan, dan penggunaan topi tidak berhubungan. Disarankan kepada Dinas Lingkungan Hidup dan Kebersihan Kota Denpasar tetap mendukung penyediaan APD serta kepatuhan para pekerja untuk memelihara higiene perorangan dan menggunakan APD yang lengkap.
\end{abstract}

Kata Kunci: Dermatitis, Higiene Perorangan, APD

\begin{abstract}
The high incidence of dermatitis due to garbage transport workers because they have a direct contact with garbage as an agent that increases the risk of occupational dermatitis. The aims of this study was to determine the association of personal hygiene and the use of PPE with the incidence of occupational dermatitis in garbage transport workers at Denpasar City Environment and Sanitation Office. This research is a quantitative study with cross sectional design. Respondents were 84 garbage transport workers in Denpasar City Environment and Sanitation Office which selected by simple random sampling. The study was conducted in March-June 2020. Data were statistically analyzed by bivariately to examine the association between variables tested. The results of this study showed the $26.19 \%$ workers had occupational dermatitis. There were association between work period, hours of work, hygiene of skin, hair and scalp, nails, hands and feet, use of gloves, clothing and trousers, and boots with occupational dermatitis. While the variables of age, education level, and hat usage did not have association with occupational dermatitis. It is necessary for support of facilities and infrastructure from the government and the need for awareness of workers to maintain personal hygiene and use the complete PPE.
\end{abstract}

Keywords: Dermatitis, Personal Hygiene, PPE

\section{PENDAHULUAN}

Sampah adalah suatu barang yang dibuang dari sumber aktivitas sesorang maupun proses alam yang belum memiliki nilai ekonomis. (Prayanti dan Kartika, 2018). Berdasarkan data DLHK Kota Denpasar Tahun 2019 volume sampah yang dihasilkan Kota Denpasar terus meningkat setiap bulannya hinnga mencapai total sebesar $921.722 \mathrm{~m}^{3}$.
Pengelolaan sampah di Kota Denpasar secara legal dilakukan oleh Dinas Lingkungan Hidup dan Kebersihan (DLHK Kota Denpasar) dengan ruang lingkup kegiatan meliputi penyapuan dan pengangkutan sampah di wilayah yang dilayani. Sistem pengelolaan di DLHK Kota Denpasar berawal dari sumber sampah (rumah tangga, tempat 
penampungan sampah sementara, kontainer). Selanjutnya sampah diangkut dari sumber sampah untuk dibawa menuju TPA. Kegiatan pengangkutan sampah tersebut setiap harinya dilakukan oleh petugas pengangkut sampah DLHK Kota Denpasar. Sampah memiliki kaitan yang erat dengan kesehatan masyarakat, karena dari sampah-sampah tersebut akan hidup berbagai mikroorganisme penyebab penyakit (bacteri pathogen).

Penyakit yang erat kaitannya dengan sampah sangat luas, dapat berupa penyakit menular, tidak menular, dapat juga mengakibat terjadinya kebakaran, dan keracunan (Faridawati, 2013). Penyakit kulit merupakan salah satu penyakit akibat sampah yang sangat rentan diderita oleh pekerja seperti petugas pengangkut sampah. Hal ini dikarenakan petugas pengangkut sampah setiap harinya mengalami kontak langsung dengan sampah sebagai agen yang meningkatkan risiko terjadinya penyakit kulit. Berdasarkan penelitian yang dilakukan kepada petugas pengangkut sampah di Kelurahan Petisan Tengah pada tahun 2016 terdapat kejadian gangguan kulit sebesar 78,1\% (Purba, 2016). Penelitian lain yang dilakukan oleh pada pemulung di TPA Suwung, Kota Denpasar juga menunjukkan terdapat kejadian gangguan penyakit kulit sebesar 54,3\% (Angriyasa et al, 2018). Insidensi penyakit kulit akan terus mengalami peningkatan karena berbagai penyebab seperti bakteri, virus, jamur yang akan berkembang biak di tempat pembuangan dan pengumpulan sampah yang dalam pengelolaan sampahnya masih kurang baik. (Mustikawati et al, 2012).

E-mail korespondensi: arya.utami@unud.ac.id
Secara nasional pencatatan kejadian penyakit kulit belum banyak dilakukan sehingga belum ada data terbaru mengenai kejadian penyakit kulit di Indonesia. Berdasarkan data riskesdas tahun 2007 prevalensi dermatitis di Indonesia sebesar 6,8\% (Kemenkes RI, 2007). Khusus di Provinsi Bali berdasarkan Profil Kesehatan Provinsi Bali tahun 2013 kejadian gangguan kulit sebesar 56.143 kasus atau $1,78 \%$ dan meningkat pada tahun 2014 sebesar 52.674 kasus atau 1,89\%, dimana Kota Denpasar menjadi daerah dengan kasus kejadian gangguan kulit tertinggi di Provinsi Bali (Saputra, 2016). Berdasarkan Data seluruh Puskesmas di Provinsi Bali tahun 2016, kasus penyakit kulit termasuk ke dalam 10 besar penyakit tertinggi dengan total penderita 37.356 orang sedangkan berdasarkan data dari Puskesmas IV Denpasar Selatan tahun 2016 diketemukan kasus penyakit kulit berada pada urutan ke tujuh dengan total 994 orang pada wilayah kerjanya.

Berdasarkan Peraturan Presiden Republik Indonesia Nomor 7 Tahun 2019 penyakit kulit merupakan salah satu penyakit akibat kerja yang digolongkan berdasarkan sistem organ. Penyakit kulit menjadi penyakit dengan kejadian tinggi sekitar 50-60\% dari seluruh penyakit akibat kerja (Laila, 2015). Dari keseluruhan kejadian penyakit kulit akibat kerja, dermatitis kontak menjadi penyakit kulit akibat kerja yang paling umum terjadi sebesar 70-90\% (Witasari \& Sukanto, 2014). Pada studi epidemiologi indonesia memperlihatkan bahwa 97\% dari 389 kasus adalah dermatitis kontak, dimana $66,3 \%$ 
diantaranya adalah dermatitis kontak iritan dan 33,7\% adalah Dermatitis kontak alergi. Insiden dermatitis kontak akibat kerja diperkirakan sebanyak 0,5 sampai 0,7 kasus per 1000 pekerja per tahun (Zania et $a l$, 2017). Kejadian penyakit kulit akibat kerja tentunya sangat berdampak terhadap produktivitas di tempat kerja. Diperkirakan dari 20-25\% kasus penyakit kulit akibat kerja yang telah dilaporkan menyebabkan kehilangan waktu kerja antara 10-20 hari kerja (Laila, 2015).

Penyakit kulit akibat kerja disebabkan oleh beberapa faktor seperti faktor lingkungan, karakteristik paparan, karakteristik agen dan faktor-faktor individu seperti umur, jenis kelamin serta hygiene perorangan (Saputra, 2016). Apabila ditinjau dari aspek keselamatan dan kesehatan kerja (K3) salah satu upaya pencegahan yang dilakukan untuk mengurangi terjadinya penyakit kulit adalah penggunaan alat pelindung diri (APD) saat bekerja (Khoinur, 2019). Berbagai macam faktor yang berhubungan dengan penyakit kulit pada petugas pengangkut sampah telah diteliti, namun hasilnya tidak konsisten. Terdapat hubungan yang signifikan antara higiene perorangan dan penggunaan APD dengan keluhan penyakit kulit (Ardiyanti, 2015). Namun sebaliknya penelitian lain menyatakan tidak ada hubungan antara higiene perorangan dan penggunaan APD dengan keluhan penyakit kulit (Butarbutar et al, 2012) Hasil yang tidak konsisten juga ditunjukkan oleh hubungan antara usia, jenis kelamin, lama bekerja, durasi bekerja perhari, jumlah hari kerja per minggu, dan penghasilan (Ardiyanti, 2015).

E-mail korespondensi: arya.utami@unud.ac.id
Berdasarkan pengamatan awal yang dilakukan pada petugas pengangkut sampah di DLHK Kota Denpasar, didapatkan hasil bahwa terdapat beberapa petugas pengangkut sampah yang mengalami keluhan gatal pada tangan, panas, dan terdapat bercak warna merah yang mulai mengering. Hasil wawancara higiene perorangan juga menunjukkan masih terdapat pekerja pengangkut sampah yang tidak mandi setelah selesai bekerja, memiliki kuku panjang dan hitam, serta terdapat petugas yang memakai pakaian kerja tanpa dicuci kembali setelah digunakan saat bekerja di hari sebelumnya. Terkait dengan penggunaan alat pelindung diri, rata-rata petugas tidak memakai alat pelindung diri seperti sarung tangan, sepatu dan topi.

\section{METODE PENELITIAN}

Desain penelitian ini merupakan penelitian analitik kuantitatif dengan pendekatan cross-sectional. Populasi target pada penelitian ini adalah petugas pengangkut sampah sedangkan populasi terjangkau pada penelitian ini adalah petugas pengangkut sampah yang terdaftar sebagai pekerja di DLHK Kota Denpasar yang berjumlah 158 orang. Sumber data adalah data primer. Perhitungan besar sampel dengan teknik penentuan untuk uji hipotesis perbedaan 2 proporsi dengan jumlah sampel minimum yaitu 84 responden dan peneliti mengunakan simple random sampling. Teknik pengumpulan data yang dilakukan dalam penelitian ini yaitu dengan cara wawancara langsung kepada responden menggunakan kuesioner yang dimuat dalam aplikasi kobotoolbox. Analisis 
kuantitatif data menggunakan teknik analisis data univariabel dan bivariabel (uji chi square dan uji keeratan hubungan). Penelitian ini telah dinyatakan layak etik oleh Komisi Etik Penelitian Litbang FK Unud/RSUP Sanglah dengan nomor 949/UN14 2.2 VII 14/LT/2020.

\section{HASIL}

Berdasarkan tabel 1 dapat diketahui bahwa sebagian besar responden berumur lebih dari 40 tahun (69,05\%) dengan tingkat pendidikan yang paling dominan yaitu pendidikan rendah $(63,10 \%)$. Responden sebagian besar memiliki masa kerja kurang dari 10 tahun $(70,24 \%)$ dengan jam kerja kurang dari 40 jam/minggu (54,76\%).
Ditinjau dari higiene perorangan, sebagian besar responden memiliki kebersihan kulit yang baik (89,29\%), kebersihan kuku, tangan dan kaki yang baik $(90,48 \%)$, serta memiliki kebersihan rambut dan kulit kepala yang baik (79,76\%). Apabila dilihat dari penggunaan APD sebagian besar responden sudah menggunakan topi (77,38\%), menggunakan baju dan celana panjang $(72,62 \%)$, serta menggunakan sepatu boot $(70,24 \%)$. Sedangkan pada pengggunaan sarung tangan sebagian besar responden tidak menggunakan sarung tangan $(66,67 \%)$.

Tabel 1. Gambaran Karakteristik Individu, Higiene Perorangan, dan Penggunaan APD

\begin{tabular}{lcc}
\hline \multicolumn{1}{c}{ Karakteristik (n=84) } & Frekuensi & Proporsi (\%) \\
\hline Umur & 26 & 30,95 \\
$\quad \leq 40$ tahun & 58 & 69,05 \\
$\quad>40$ tahun & & \\
Masa Kerja & 59 & 70,24 \\
$\quad \leq 10$ tahun & 25 & 29,75 \\
$\quad>10$ tahun & & \\
Tingkat Pendidikan & 53 & 63,10 \\
$\quad$ Rendah & 31 & 36,90 \\
$\quad$ Tinggi & & \\
Jam Kerja & 46 & 54,76 \\
$\quad \leq 40$ jam/minggu & 38 & 45,24 \\
$\quad>40$ jam/minggu & & \\
Kebersihan Kulit & 75 & 89,29 \\
$\quad$ Baik & 9 & 10,71 \\
$\quad$ Buruk & & \\
Kebersihan Kuku, Tangan \& Kaki & 76 & 90,48 \\
$\quad$ Baik & 8 & 9,52 \\
$\quad$ Buruk & & 79,76 \\
Kebersihan Rambut dan Kulit Kepala & 67 & 20,24 \\
$\quad$ Baik & 17 & 77,38 \\
$\quad$ Buruk & & \\
Penggunaan Topi & 65 & \\
$\quad$ Ya & & \\
E-mail korespondensi: arya.utami@unud.ac.id & &
\end{tabular}




\begin{tabular}{lcc}
\hline Karakteristik (n=84) & Frekuensi & Proporsi (\%) \\
\hline Tidak & 19 & 22,62 \\
Penggunaan Baju dan Celana Panjang & & \\
$\quad$ Ya & 61 & 72,62 \\
Tidak & 23 & 27,38 \\
Penggunaan Sarung Tangan & & \\
Ya & 28 & 33,33 \\
Tidak & 56 & 66,67 \\
Penggunaan Sepatu Boot & & \\
Ya & 59 & 70,24 \\
Tidak & 25 & 29,76 \\
\hline
\end{tabular}

Pada tabel 2 dari 84 responden didapatkan hasil sebanyak (26,19\%) responden pernah mengalami gatal-gatal. Dari keseluruhan responden yang mengalami gatal-gatal seluruhnya terjadi setelah mereka mengalami kontak dengan sampah. Seluruh responden yang mengalami gejala gatal menyatakan gejala gatal yang dialami pada kulit terjadi setelah mereka bekerja sebagai pekerja pengangkut sampah. Dari keseluruhan responden yang mengalami keluhan gatal $45,45 \%$ diantaranya memiliki keluhan lain selain gatal seperti bercak kemerahan kulit mengelupas, bentol-bentol, kulit mongering, penebalan kulit, dan lainnya.

Pada tabel 3 berdasarkan hasil wawancara kuesioner anamnesis dermatitis kontak akibat kerja sebanyak $26,19 \%$ responden mengalami dermatitis kontak akibat kerja.

Tabel 2. Gambaran Anamnesis Kejadian Dermatitis Kontak Akibat Kerja

\begin{tabular}{|c|c|c|c|c|c|}
\hline \multirow{2}{*}{ No } & \multirow{2}{*}{ Pernyataan } & \multicolumn{2}{|c|}{ Ya } & \multicolumn{2}{|c|}{ Tidak } \\
\hline & & $\mathbf{n}$ & $\%$ & $\mathbf{N}$ & $\%$ \\
\hline 1. & $\begin{array}{l}\text { Pernah mengalami keluhan pada kulit } \\
(\mathbf{n}=\mathbf{8 4})\end{array}$ & 25 & 29,76 & 59 & 70,24 \\
\hline 2. & $\begin{array}{l}\text { Keluhan pada kulit berupa rasa gatal } \\
\text { gatal }(\mathbf{n}=\mathbf{2 5})\end{array}$ & 22 & 88,00 & 3 & 12,00 \\
\hline 3. & $\begin{array}{l}\text { Pada keluhan gatal dirasakan setelah } \\
\text { bekerja sebagai petugas pengangkut } \\
\text { sampah }(\mathbf{n}=\mathbf{2 2})\end{array}$ & 22 & 100,00 & 0 & 00,00 \\
\hline 4. & $\begin{array}{l}\text { Keluhan gatal pada kulit dirasakan } \\
\text { setelah kontak dengan sampah sewaktu } \\
\text { bekerja }(\mathbf{n}=\mathbf{2 2})\end{array}$ & 22 & 100,00 & 0 & 00,00 \\
\hline 5. & $\begin{array}{l}\text { Keadaan kulit membaik dan sembuh } \\
\text { apabila berhenti bekerja untuk sementara } \\
\text { waktu ( } \mathbf{n = 2 2})\end{array}$ & 22 & 100,00 & 0 & 00,00 \\
\hline 6. & Terdapat keluhan lain selain gatal $(\mathbf{n}=\mathbf{2 2})$ & 10 & 45,45 & 12 & 55,55 \\
\hline
\end{tabular}

E-mail korespondensi: arya.utami@unud.ac.id 


\begin{tabular}{lcccc}
\hline Bercak Kemerahan $(\mathbf{n}=\mathbf{1 0})$ & 4 & 40,00 & 6 & 60,00 \\
Kulit Mengelupas $(\mathbf{n}=\mathbf{1 0})$ & 5 & 50,00 & 5 & 50,00 \\
$\quad$ Kulit Mengering $(\mathbf{n}=\mathbf{1 0})$ & 5 & 50,00 & 5 & 50,00 \\
$\quad$ Penebalan Kulit $(\mathbf{n}=\mathbf{1 0})$ & 1 & 10,00 & 9 & 50,00 \\
$\quad$ Lainnya $(\mathbf{n}=\mathbf{1 0})$ & 1 & 10,00 & 9 & 90,00 \\
$\quad$ Lama mengalami kelainan pada kulit & & & & \\
$\quad(\mathbf{n}=\mathbf{2 2})$ & 19 & 86,36 & 3 & 13,64 \\
$\quad<1$ tahun $(\mathbf{n}=\mathbf{2 2})$ & 3 & 13,64 & 19 & 86,36 \\
$\quad \geq 1$ tahun $(\mathbf{n}=\mathbf{2 2})$ & & & & \\
\hline
\end{tabular}

Tabel 3. Kejadian Dermatitis Kontak Akibat Kerja pada Pekerja Pengangkut Sampah DLHK Kota Denpasar

\begin{tabular}{lcc}
\hline Variabel & Frekuensi (n) & Proporsi (\%) \\
\hline Kejadian Dermatitis Kontak Akibat Kerja & & \\
Ya & 22 & 26,19 \\
Tidak & 62 & 73,81 \\
\hline
\end{tabular}

Tabel 4. Hasil Analisis Bivariabel Hubungan Karakteristik Individu, Higiene Perorangan dan Penggunaan APD dengan Kejadian Dermatitis Kontak Akibat Kerja

\begin{tabular}{|c|c|c|c|c|c|c|c|c|}
\hline \multirow{3}{*}{ Variabel } & \multicolumn{4}{|c|}{$\begin{array}{c}\text { Dermatitis kontak } \\
\text { Akibat Kerja }\end{array}$} & \multirow[t]{3}{*}{ Total (n) } & \multirow[t]{3}{*}{ PR } & \multirow[t]{3}{*}{$95 \%$ CI } & \multirow[t]{3}{*}{$P$} \\
\hline & \multicolumn{2}{|c|}{$\mathrm{Ya}$} & \multicolumn{2}{|c|}{ Tidak } & & & & \\
\hline & $\mathbf{n}$ & $\%$ & $\mathbf{N}$ & $\%$ & & & & \\
\hline \multicolumn{9}{|l|}{ Umur } \\
\hline$>40$ tahun & 13 & 22,41 & 45 & 77,59 & 58 & 0,64 & $0,31-1,32$ & 0,23 \\
\hline$\leq 40$ tahun & 9 & 34,62 & 17 & 65,38 & 26 & Ref & & \\
\hline \multicolumn{9}{|l|}{ Masa Kerja } \\
\hline$>10$ tahun & 19 & 76,00 & 6 & 24,00 & 25 & 14,93 & $4,85-46,00$ & 0,00 \\
\hline$\leq 10$ tahun & 3 & 5,08 & 56 & 94,92 & 59 & Ref & & \\
\hline \multicolumn{9}{|l|}{ Tingkat Pendidikan } \\
\hline Tinggi & 5 & 16,13 & 26 & 83,87 & 31 & 0,50 & $0,20-1,22$ & 0,10 \\
\hline Rendah & 17 & 32,08 & 36 & 67,92 & 53 & Ref & & \\
\hline \multicolumn{9}{|l|}{ Jam Kerja } \\
\hline$>40 \mathrm{jam} / \mathrm{minggu}$ & 16 & 42,11 & 22 & 57,89 & 38 & 3,22 & $1,40-7,43$ & 0,002 \\
\hline$\leq 40 \mathrm{jam} / \mathrm{minggu}$ & 6 & 13,04 & 40 & 86,96 & 46 & Ref & & \\
\hline \multicolumn{9}{|l|}{ Kebersihan Kulit } \\
\hline Buruk & 7 & 77,78 & 2 & 22,22 & 9 & 3,88 & $2,19-6,88$ & 0,0002 \\
\hline Baik & 15 & 20,00 & 60 & 80,00 & 75 & $\operatorname{Ref}$ & & \\
\hline \multicolumn{9}{|c|}{ Kebersihan Kuku, Tangan, dan Kaki } \\
\hline Buruk & 6 & 75,00 & 2 & 25,00 & 8 & 3,56 & $1,97-6,43$ & 0,0010 \\
\hline Baik & 16 & 21,05 & 60 & 78,95 & 76 & Ref & & \\
\hline \multicolumn{9}{|c|}{ Kebersihan Rambut dan Kulit Kepala } \\
\hline Buruk & 13 & 76,47 & 4 & 23,53 & 17 & 5,69 & $2,93-11,04$ & 0,000 \\
\hline
\end{tabular}

E-mail korespondensi: arya.utami@unud.ac.id 


\begin{tabular}{|c|c|c|c|c|c|c|c|c|}
\hline \multirow{4}{*}{ Variabel } & \multicolumn{4}{|c|}{ Dermatitis kontak } & \multirow{4}{*}{ Total (n) } & \multirow{4}{*}{ PR } & \multirow{4}{*}{$95 \% \mathrm{CI}$} & \multirow{4}{*}{$P$} \\
\hline & & Akibat & Ker & & & & & \\
\hline & \multicolumn{2}{|c|}{ Ya } & \multicolumn{2}{|c|}{ Tidak } & & & & \\
\hline & $\mathbf{n}$ & $\%$ & $\mathbf{N}$ & $\%$ & & & & \\
\hline Baik & 9 & 13.43 & 58 & 86.57 & 67 & Ref & & \\
\hline \multicolumn{9}{|l|}{ Penggunaan Topi } \\
\hline Tidak & 6 & 31,58 & 13 & 68,42 & 19 & 1,28 & $0,58-2,81$ & 0,543 \\
\hline Ya & 16 & 24.62 & 49 & 75.38 & 65 & Ref & & \\
\hline \multicolumn{9}{|c|}{ Penggunaan Baju dan Celana Panjang } \\
\hline Tidak & 12 & 52,17 & 11 & 47,83 & 23 & 3,19 & $1,59-633$ & 0,0009 \\
\hline Ya & 10 & 16,39 & 51 & 83,61 & 61 & Ref & & \\
\hline \multicolumn{9}{|c|}{ Penggunaan Sarung Tangan } \\
\hline Tidak & 20 & 35,71 & 36 & 64,29 & 56 & 5,00 & $1,25-19,89$ & 0,005 \\
\hline Ya & 2 & 7,14 & 26 & 92,86 & 28 & Ref & & \\
\hline \multicolumn{9}{|c|}{ Penggunaan Sepatu Boot } \\
\hline Tidak & 11 & 44,00 & 14 & 56,00 & 25 & 2,36 & $1,18-4,71$ & 0,0157 \\
\hline $\mathrm{Ya}$ & 11 & 18,46 & 48 & 81,36 & 59 & Ref & & \\
\hline
\end{tabular}

Pada tabel 4 hasil analisis bivariat menunjukkan variabel masa kerja memiliki hubungan dengan kejadian dermatitis kontak akibat kerja dimana responden dengan masa kerja lebih dari 10 tahun meningkatkan risiko 14,93 kali mengalami dermatitis kontak akibat kerja ( $\mathrm{PR}=14,93$; 95\% CI: 4,85-46,00). Variabel jam kerja memiliki hubungan dengan kejadian dermatitis kontak akibat kerja dimana responden dengan jam kerja lebih dari 40 jam/minggu meningkatkan risiko 3,22 kali mengalami dermatitis kontak akibat kerja (PR=3,22; 95\% CI: 1.40-7,43).

Apabila ditinjau dari hygiene perorangan variabel kebersihan kulit memiliki hubungan dengan kejadian dermatitis kontak akibat kerja dimana responden dengan kebersihan kulit yang buruk meningkatkan risiko 3,88 kali mengalami dermatitis kontak akibat kerja $(\mathrm{PR}=3,88 ;$ 95\% CI: 2,19-6,88). Variabel kebersihan kuku, tangan dan kaki memiliki hubungan kejadian dermatitis kontak akibat kerja dimana responden dengan kebersihan kuku, tangan dan kaki yang buruk meningkatkan risiko 3,56 kali mengalami dermatitis kontak akibat kerja $(\mathrm{PR}=3,56$; 95\% CI: 1,97-6,43). Variabel kebersihan rambut dan kulit kepala memiliki hubungan dengan kejadian dermatitis kontak akibat kerja dimana responden dengan kebersihan rambut dan kulit kepala yang buruk meningkatkan risiko 5,69 kali mengalami dermatitis kontak akibat kerja (PR= 5,69 ; 95\% CI: 2,9311,04).

Apabila ditinjau dari penggunaan APD variabel penggunaan baju dan celana panjang memiliki hubungan dengan kejadian dermatitis kontak akibat kerja dimana responden yang tidak memakai baju dan celana panjang meningkatkan risiko 3,19 kali mengalami dermatitis kontak akibat kerja (PR=3,19 ; 95\% CI: 1,59$6,33)$. Variabel penggunaan sarung tangan memiliki hubungan dengan kejadian dermatitis kontak akibat kerja dimana 
responden yang tidak memakai sarung tangan meningkatkan risiko 5,00 kali mengalami dermatitis kontak akibat kerja (PR= 5,00 ; 95\% CI: 1,25-19,89). Variabel penggunaan sepatu boot memiliki hubungan dengan kejadian dermatitis kontak akibat kerja dimana responden yang tidak memakai sepatu boot meningkatkan risiko 2.36 kali mengalami dermatitis kontak akibat kerja $(\mathrm{PR}=2,36$; 95\% CI: 1,18-4,71).

Variabel lain seperti umur, tingkat pendidikan, serta penggunaan topi tidak memiliki hubungan dengan kejadian dermatitis kontak akibat kerja $(p>0,05)$.

\section{DISKUSI}

Penetapan anamnesis dermatitis kontak akibat kerja dilihat dari responden yang mengalami gejala utama dermatitis berupa rasa gatal, responden yang mengalami gejala utama dermatitis kontak akibat kerja setelah kontak dengan sampah, keluhan tersebut dirasakan setelah bekerja sebagai petugas pengangkut sampah di DLHK Kota Denpasar, serta terjadi pengurangan keluhan apabila berhenti melakukan aktivitas di tempat kerja. Dalam Peraturan Presiden Republik Indonesia Nomor 7 Tahun 2019 dermatitis kontak merupakan salah satu penyakit yang termasuk dalam penyakit kulit akibat kerja. Berdasarkan hasil wawancara terdapat sebanyak $73,81 \%$ responden tidak mengalami dermatitis kontak akibat kerja dan sebanyak 26,19\% responden mengalami dermatitis kontak akibat kerja. Hasil ini lebih rendah jika dibandingkan dengan kejadian dermatitis kontak pada petugas pengelola sampah terpadu di Dinas Lingkungan Hidup E-mail korespondensi: arya.utami@unud.ac.id
Kabupaten Jember dengan proporsi sebesar 63,30\% (Trismariyani, 2018).

Apabila dilihat dari keseluruhan responden yang tidak mengalami dermatitis kontak akibat kerja terdapat $4,83 \%$ diantaranya mengalami keluhan selain gatal seperti bercak kemerahan, kulit mengelupas, bentol-bentol, kulit mengering, penebalan kulit, namun tidak disertai gatal sebagai gejala awal sehingga dikategorikan tidak menderita dermatitis kontak akibat kerja. Pada keseluruhan responden yang mengalami dermatitis kontak akibat kerja 45,45\% diantaranya memiliki keluhan lain selain gatal seperti bercak kemerahan kulit mengelupas, bentol-bentol, kulit mengering, penebalan kulit, dan lainnya. Hal ini sejalan dengan penelitian yang menyatakan gejala awal yang umum terjadi pada dermatitis kontak yaitu rasa gatal dan kemerahan pada kulit. Sedangkan pada bentuk kronis akan terbentuk skuama, kusta, dan penebalan pada kulit (Salamah, 2012). Pada dunia industri usia pekerja yang lebih tua menjadi lebih rentan terhadap bahan iritan. Seringkali pada usia lanjut terjadi kegagalan dalam pengobatan dermatitis kontak, sehingga timbul dermatitis kronik (Indrawan et al, 2014).

Hasil uji statistik pada variabel umur menunjukkan tidak terdapat hubungan antara umur dengan kejadian dermatitis kontak akibat kerja. Penelitian ini sejalan dengan penelitian pada pemulung Laskar Mandiri di Kecamatan Bantar Gebang tahun 2013 yang menyatakan tidak terdapat hubungan antara umur dengan kejadian penyakit kulit (Faridawati, 2013). 
Arc. Com. Health • Agustus 2021

p-ISSN 2302-139X e-ISSN 2527-3620

Vol. 8 No. 2: 325 - 342

Tidak adanya hubungan antara umur dengan kejadian dermatitis kontak akibat kerja pada penelitian ini diduga karena sebagian besar responden dalam penelitian ini memiliki umur $>40$ tahun sehingga data penelitian yang diperoleh kurang bervariasi. Selain itu pada studi literatur lain terdapat perbedaan metode dan jumlah sampel penelitian sehingga memengaruhi hasil penelitian. Dermatitis kontak dapat menyerang semua kelompok usia, artinya usia bukan merupakan faktor resiko utama terhadap paparan bahanbahan penyebab dermatitis kontak (Susanty, 2015).

Berdasarkan hasil penelitian pada pekerja pengangkut sampah DLHK Kota Denpasar kejadian dermatitis kontak akibat kerja dominan terjadi pada responden yang berumur $\leq 40$ tahun $(34,62 \%)$. Hal ini sejalan dengan penelitian yang dilakukan pada pekerja Rumah Kompos Jambangan Surabaya dimana kejadian dermatitis kontak paling banyak dialami oleh pekerja usia 15-39 tahun sebanyak 71,4\%. Pekerja muda mempunyai peluang 2,824 kali terkena dermatitis kontak dibandingkan dengan dengan pekerja tua (Lestari, 2007). Selain itu tingginya kejadian dermatitis kontak akibat kerja pada pekerja pengangkut sampah DLHK Kota Denpasar diduga karena mayoritas pekerja usia muda mengambil jam kerja lebih banyak yaitu 2 shift dengan jumlah jam kerja $>40$ jam/minggu dibanding pekerja usia tua yang sebagaian besar hanya bekerja 1 shift per harinya. Hal ini menyebabkan pekerja usia muda mengami intensitas paparan sampah lebih banyak dibandingkan pekerja usia tua.

Berdasarkan hasil uji statistik terdapat hubungan antara masa kerja dengan dermatitis kontak akibat kerja. Hal ini sejalan dengan penelitian pada petugas pengangkut sampah Kota Tangerang Selatan tahun 2018 yang menyatakan terdapat hubungan yang signifikan antara masa kerja dengan gangguan kulit (Azizah et al, 2018). Berdasarkan hasil wawancara kepada responden sebagian besar kejadian dermatitis kontak akibat kerja terjadi pada responden dengan masa kerja lebih dari 10 tahun $(76,00 \%)$. Hal ini dapat terjadi dikarenakan semakin lama masa kerja responden akan semakin meningkatkan risiko dermatitis kontak pada pekerja pengangkut sampah. Pekerja yang lebih lama bekerja akan meningkatkan risiko terjadinya gangguan kulit karena lebih banyak terpajan bahan iritan (Azizah et al, 2018).

Hasil uji statistik pada variabel tingkat pendidikan menunjukkan tidak terdapat hubungan tingkat pendidikan dengan kejadian dermatitis kontak akibat kerja pada pekerja pengangkut sampah DLHK Kota Denpasar. Peneltian ini sejalan dengan penelitian pada pemulung dimana tingkat pengetahuan tidak memiliki hubungan dengan kejadian penyakit kulit (tinea pedis) (Darung, 2018). Hal ini mungkin dikarenakan tingkat pendidikan bukan merupakan faktor yang secara langsung dapat menyebabkan terjadinya dermatitis kontak akibat kerja. Menurut teori Lawrence Green, tingkat pendidikan merupakan salah satu faktor predisposisi (faktor pemudah) untuk mempermudah terwujudnya perilaku kesehatan (Notoatmodjo, 2012). 
Pada variabel tingkat penddikan hasil wawancara dengan responden menunjukkan hasil kejadian dermatitis kontak akibat kerja paling besar terjadi pada responden dengan tingkat pendidikan rendah (32,08\%). Hal ini dikarenakan semakin tinggi tingkat pendidikan seseorang, maka akan berkembang pula pola pikir seseorang, dan akan berujung kepada kesadaran diri untuk menjaga kesehatan sehingga terhindar dari berbagai penyakit (Girsang \& Tobing, 2010).

Hasil uji statistik menunjukkan variabel jam kerja memiliki hubungan dengan kejadian dermatitis kontak akibat kerja. Penelitian ini sejalan dengan penelitian pada petani rumput laut di Desa Akuni yang menyatakan terdapat hubungan bermakna antara lama kontak dengan kejadian dermatitis kontak (Safriyanti et al, 2016).

Sebagian besar responden yang mengalami dermatitis kontak akibat kerja memiliki jam kerja $>40$ jam/minggu $(42,11 \%)$. Hal ini sejalan dengan penelitian di TPST Kecamatan Bantar Gebang tahun 2017 dimana sebagian besar responden yang mengalami penyakit kulit memiliki jam kerja diatas nilai ambang batas (66,7\%) (Srisantyorini \& Cahyaningsih, 2019). Hal ini dikarenakan semakin lama sesorang terpapar dengan agent dan lingkungan kerja akan meningkatkan risiko terjadinya dermatitis kontak akibat kerja. Memperpanjang waktu kerja lebih dari nilai ambang batas biasanya tidak disertai efisiensi, efektivitas, dan produktivitas kerja yang optimal, bahkan bisa terjadi penurunan kualitas dan hasil kerja, serta apabila bekerja dilakukan secara E-mail korespondensi: arya.utami@unud.ac.id berkepanjangan akan menimbulkan terjadinya kelelahan, gangguan kesehatan, dan penyakit akibat kerja (Faridawati, 2013).

Berdasarkan hasil uji statistik terdapat hubungan antara kebersihan kulit dengan kejadian dermatitis kontak akibat kerja. Hal ini sejalan dengan penelitian pada respoden di Kelurahan yang menyatakan kebersihan kulit mempunyai hubungan signifikan dengan keluhan penyakit kulit (Sajida, 2012).

Dari hasil wawancara juga ditemukan kejadian dermatitis kontak akibat kerja paling tinggi terjadi pada responden yang memiliki kebersihan kulit buruk $(77,78 \%)$. Hal ini sejalan dengan penelitian di Kelurahan Denai Tahun 2012 dimana sebagian besar kejadian penyakit kulit terjadi pada responden dengan kebersihan kulit yang buruk dengan proporsi sebesar 82,9\% (Sajida, 2012). Berdasarkan hasil wawancara dengan responden masih terdapat responden yang tidak langsung mandi setelah selesai bekerja, selain itu terdapat responden yang tidak mengganti baju kerjanya setiap hari. Hal itu menyebabkan pekerja lebih rentan mengalami kejadian dermatitis kontak akibat kerja. Kebersihan perorangan pekerja agar terhindar dari dermatitiis akibat kerja yaitu mencuci tangan, mandi sebelum pulang kerja, pakaian bersih dan berganti pakaian setiap hari Pemakaian baju kerja yang bersih dianjurkan karena pakaian yang terkontaminasi dapat menyebabkan dermatitis (Suma'mur, 2009)

Berdasarkan hasil uji statistik terdapat hubungan antara kebersihan rambut dan kulit kepala dengan kejadian dermatitis kontak akibat kerja. Penelitian 
Arc. Com. Health • Agustus 2021

p-ISSN 2302-139X e-ISSN 2527-3620

Vol. 8 No. 2: 325 - 342

ini sejalan dengan penelitian pada petugas pengangkut sampah Kota Tangerang Selatan Tahun 2018 yang menyatakan terdapat hubungan antara kebersihan rambut dengan kejadian penyakit kulit pada (Azizah et al, 2018).

Berdasarkan hasil wawancara didapatkan hasil sebagian besar responden memiliki kebersihan rambut dan kulit kepala yang baik (79,76\%). Kejadian dermatitis kontak akibat kerja paling tinggi terjadi pada responden yang memiliki kebersihan rambut dan kulit kepala yang buruk (76,41\%). Hal ini sejalan dengan penelitian pada petugas pengangkut sampah Kota Tangerang Selatan yang menyatakan responden yang memiliki kebersihan rambut dan kulit kepala buruk mengalami gangguan kulit lebih banyak dengan proporsi sebesar 82,86 \% (Azizah et al, 2018).

Hasil wawancara menunjukkan masih terdapat responden yang tidak mencuci rambut segera setelah kontak dengan sampah, selain itu kondisi rambut dan kepala responden dalam keadaan kotor dan terdapat $47,62 \%$ responden yang tidak menggunakan alat-alat pemeliharaan rambut sendiri. Kurangnya kebersihan rambut seseorang akan membuat penampilan rambut tampak kusut, kusam, tidak rapi dan tampak acak- acakan, bahkan gangguan kesehatan seperti gangguan kesehatan pada batang rambut dan kulit kepala diantaranya adalah infeksi jamur yang terjadi pada permukaan batang rambut dan di dalam korteks batang rambut, adanya serangga seperti kutu rambut, kerusakan zat tanduk akibat pemakaian sisir yang terlalu keras atau pemakaian shampo yang tidak sesuai

(Isro'in 2012). Kebersihan rambut yang buruk juga dapat menyebabkan keluhan kulit, karena kotoran-kotoran rambut yang berasal dari aktifitas yang kita lakukan akan menempel di kulit kepala dan membuat kulit kepala menjadi gatal- gatal (Kusumaningrum \& Widayati, 2017). Berdasarkan hasil uji statistik terdapat hubungan antara kebersihan kuku, tangan, dan kaki dengan kejadian dermatitis kontak akibat kerja. Hal ini sejalan dengan penelitian pada pemulung di TPA Tanjung Rejo Kabupaten Kudus Tahun 2015 yang menyatakan kebersihan kuku, tangan dan kaki mempunyai hubungan signifikan dengan keluhan penyakit kulit (Kusnin, 2015).

Berdasarkan hasil wawancara didapatkan hasil sebagian besar responden memiliki kebersihan kuku, tangan, dan kaki yang baik (90.48\%). Kejadian dermatitis kontak akibat kerja paling tinggi terjadi pada responden yang memiliki kebersihan kuku, tangan, dan kaki yang buruk $(75.00 \%)$. Hal ini sejalan dengan penelitian pada petugas pengangkut sampah Kota Tangerang Selatan Tahun 2018 dimana sebagian besar kejadian penyakit kulit terjadi pada responden dengan kebersihan kuku dan kaki yang buruk dengan mengalami keluhan gangguan kulit sebesar 85,71\% (Azizah et al, 2018).

Hasil wawancara juga menunjukkan masih terdapat responden yang tidak mencuci tangan segera setelah kontak dengan sampah, kondisi kuku tangan dan kaki responden dalam keadaan kotor, serta masih terdapat responden yang tidak rutin memotong kuku minimal seminggu sekali. Tentu saja hal tersebut 
menyebabkan pekerja lebih rentan mengalami kejadian dermatitis kontak akibat kerja dikarekanan tangan dan kaki merupakan bagian tubuh yang paling sering mengalami kontak langsung dengan sampah, karena seringkali petugas pengangkut sampah harus naik ke atas timbunan sampah untuk memindahkan sampah ke dalam truk ataupun menurunkan dari atas truk saat proses pengangkutan.

Kebersihan tangan yang buruk dan kuku yang panjang dapat menyebabkan perkembangan kuman penyakit kulit akibat garukan kulit yang mengalami infeksi (Kusnin, 2015). Kebersihan kuku, tangan dan kaki dapat dilakukan dengan memotong kuku minimal seminggu sekali serta mencuci tangan dan kaki dengan sabun setelah kontak langsung dengan sampah. Mencuci tangan dengan sabun sangat efektif untuk mencegah penularan penyakit karena lemak dan kotoran yang menempel akan terlepas saat tangan digosok dan bergesek saat dibilas. Lemak dan kotoran yang menempel inilah menjadi tempat kuman penyakit hidup (Kushartanti, 2012).

Apabila ditinjau dari penggunaan APD hasil uji statistik menujukkan penggunaan topi tidak berhubungan dengan kejadian dermatitis kontak akibat kerja. Hal ini juga sejalan dengan penelitian pada petugas pengelola sampah di Tempat Pembuangan Akhir (TPA) Tanjung Kramat yang menunjukkan bahwa pemakaian alat pelindung topi tidak ada hubungan yang bermakna dengan kejadian penyakit kulit (Hiola, 2012).

Apabila ditinjau dari penggunaan topi, kejadian dermatitis kontak akibat E-mail korespondensi: arya.utami@unud.ac.id kerja paling tinggi terjadi pada responden yang tidak menggunakan topi (31,58\%) sedangkan pada responden yang tidak menggunakan topi kejadian dermatitis kontak akibat kerja sebesar (24,62\%). Tidak adanya hubungan antara penggunaan topi dengan kejadian dermatitis kontak akibat kerja diduga karena terdapat jumlah yang hampir sama antara proporsi responden yang menggunakan topi dan mengalami dermatitis kontak akibat kerja dengan jumlah proporsi responden yang tidak menggunakan topi dan mengalami dermatitis kontak akibat kerja. Selain itu hasil temuan di lapangan menunjukkan topi yang digunakan responden saat bekerja terlihat dalam keadaan yang kotor dan sudah usang. Hal tersebut terjadi dikarenakan penyediaan alat pelindung diri dari DLHK Kota Denpasar hanya dilakukan setiap setahun sekali, sehingga responden jarang mencuci ataupun mengganti topi yang digunakan. Selain itu jika dibandingkan dengan tangan ataupun kaki, bagian kepala dan rambut merupakan bagian tubuh yang paling rendah memiliki intensitas kontak dengan sampah hal ini menyebabkan responden dengan penggunaan topi yang baik juga dapat terkena dermatitis kontak akibat kerja apabila tidak disertai dengan penggunaan alat pelindung diri lainnya. Faktor yang menyebabkan ketidaksesuaian penggunaan alat pelindung diri pada pemulung dikarenakan tidak ada yang menyediakannya alat pelindung diri yang sesuai untuk digunakan, kurangnya pengetahuan pekerja mengenai jenis alat pelindung diri yang sesuai, serta pendapatan pemulung yang rendah juga termasuk salah satu faktor yang 
Arc. Com. Health • Agustus 2021

p-ISSN 2302-139X e-ISSN 2527-3620

Vol. 8 No. 2: 325 - 342

mempengaruhi perilaku penggunaan alat pelindung diri karena mereka kurang mampu untuk membeli alat pelindung diri yang sesuai dengan kebutuhan sehingga memaksa mereka untuk menggunakan alat pelindung diri yang tidak sesuai (Srisantyorini \& Cahyaningsih, 2019).

Berdasarkan hasil uji statistik terdapat hubungan antara penggunaan baju dan celana panjang dengan kejadian dermatitis kontak akibat kerja pada pekerja pengangkut sampah DLHK Kota Denpasar. Hal ini sejalan dengan penelitian pada pekerja pengupas udang di Kecamatan Medan Labuhan Tahun 2012 yang menyatakan terdapat hubungan yang bermakna antara pemakaian pakaian kerja dengan keluhan gangguan kulit (Aisyah, 2012). Pakaian kerja berfungsi untuk melindungi kulit tubuh dari berbagai macam bakteri yang terdapat pada sampah (Mustikawati et al, 2012). Apabila ditinjau dari penggunaan baju dan celana panjang kejadian dermatitis kontak pada pekerja yang tidak menggunakan baju dan celana panjang sebesar 52,17\% lebih besar jika dibandingkan responden yang menggunakan baju dan celana panjang dan menderita dermatitis kontak akibat kerja (16,39\%). Hal ini dikarekakan tidak semua responden memiliki jumlah baju dan celana panjang yang memadai. Hasil temuan di lapangan didapatkan bahwa mereka menggunakan kaos pendek dan celana panjang, ada juga sebagian yang menggunakan pakaian panjang namun menggunakan celana pendek. Selain itu kondisi pakaian yang digunakan responden terlihat dalam keadaan kotor dan usang. Hal ini sejalan dengan penelitian yang dilakukan di TPA Kedaung

Wetan yang menyaatakan responden dengan kebiasaan ganti pakaian yang tidak baik dan menderita penyakit kulit sebesar 88\% (Mustikawati et al, 2012).

Hasil uji statistik menunjukkan terdapat hubungan antara penggunaan sarung tangan dengan kejadian dermatitis kontak akibat kerja pada pekerja pengangkut sampah DLHK Kota Denpasar. Hal ini sejalan dengan penelitian pada petugas pengelola sampah di TPA Tanjung Kramat yang menyatakan terdapat hubungan antara penggunaan sarung tangan dengan penyakit kulit (Hiola, 2012). Penggunaan sarung tangan berfungsi untuk meminimalisir terjadinya kontak langsung kulit tangan dengan kotoran dan benda tajam yang terdapat dalam sampah sehingga terhindar dari dermatitis kontak akibat kerja. Penggunaan alat pelindung diri seperti sarung tangan menjadi penting, karena penggunaan alat pelindung diri bertujuan untuk melindungi tubuh dari bahaya pekerjaan yang dapat mengakibatkan penyakit atau kecelakaan kerja (Dewi et al, 2016) .

Apabila ditinjau dari penggunaan sarung tangan kejadian dermatitis kontak pada pekerja yang tidak menggunakan sarung tangan sebesar 35,71\% lebih besar jika dibandingkan responden yang menggunakan sarung tangan dan menderita dermatitis kontak akibat kerja (7,14\%). Sebagian besar responden tidak menggunakan sarung tangan beralasan mereka tidak membawa sarung tangan. Hal ini dikarenakan sarung tangan yang diberikan oleh DLHK Kota Denpasar hanya mempu bertahan selama beberapa bulan dari kerusakan akibat digunakan bekerja mengangkut sampah. Apabila 
sarung tangan responden rusak mereka harus menunggu untuk mendapat sarung tangan di tahun berikutnya. Selain itu beberapa responden mengatakan mereka tidak menggunakan sarung tangan dikarenakan rasa tidak nyaman yang ditimbulkan saat penggunaan sarung tangan seperti tangan menjadi lembab serta mudah tersangkut. Penggunaan sarung tangan yang rendah disebabkan oleh pola berfikir pekerja yang kurang baik karena menurut pekerja penggunaan sarung tangan mengurangi produktifitas pekerjaan (Mustikawati et al, 2012).

Hasil uji statistik menunjukkan terdapat hubungan antara penggunaan sepatu boot dengan kejadian dermatitis kontak akibat kerja pada pekerja pengangkut sampah DLHK Kota Denpasar. Hal ini sejalan dengan penelitian di TPA Jatibarang Semarang yang menyatakan terdapat hubungan antara penggunaan sepatu boot dengan kejadian penyakit jamur kuku pada pekerja pengangkut sampah (Maharani et al, 2016). Tujuan pemakaian sepatu boot berbahan karet adalah agar meminimalisir terjadinya kontak langsung dengan kotoran ataupun benda tajam yang terdapat dalam sampah (Mustikawati et al, 2012).

Apabila ditinjau dari penggunaan sepatu boot kejadian dermatitis kontak pada pekerja yang tidak menggunakan sepatu boot sebesar 44,00\% lebih besar jika dibandingkan responden yang menggunakan sepatu boot dan menderita dermatitis kontak akibat kerja $(18,46 \%)$. Sebagian besar responden yang tidak menggunakan sepatu boot beralasan mereka tidak membawa sepatu. Hal ini dikarenakan sepatu boot yang diberikan E-mail korespondensi: arya.utami@unud.ac.id oleh DLHK Kota Denpasar hanya mempu bertahan selama beberapa bulan dari kerusakan akibat digunakan bekerja mengangkut sampah. Apabila sepatu boot responden rusak mereka harus menunggu untuk mendapat sepatu boot di tahun berikutnya. Selain itu terdapat beberapa responden yang merasa tidak nyaman saat menggunakan sepatu boot karena menyebabkan kaki terasa gerah.

\section{SIMPULAN}

Kejadian dermatitis kontak pada pekerja pengangkut sampah DLHK Kota Denpasar sebesar 26,19\%. Pada variabel karakteristik individu terdapat hubungan antara jam kerja dan masa kerja dengan kejadian dermatitis kontak akibat kerja pada pekerja pengangkut sampah DLHK Kota Denpasar. Responden dengan jam kerja $>10$ tahun dan $>40$ jam/minggu meningkatkan risiko mengalami kejadian dermatitis kontak akibat kerja.

Pada variabel hygiene perorangan terdapat hubungan antara kebersihan kulit, kebersihan kuku tangan dan kaki, kebersihan rambut dan kulit kepala dengan kejadian dermatitis kontak akibat kerja pada pekerja pengangkut sampah DLHK Kota Denpasar. Responden dengan hygiene perorangan yang buruk meningkatkan risiko mengalami kejadian dermatitis kontak akibat kerja.

Pada variabel penggunaan APD terdapat hubungan antara pemakaian baju dan celana panjang, penggunaan sarung tangan, penggunaan sepatu boot dengan kejadian dermatitis kontak akibat kerja pada pekerja pengangkut sampah DLHK Kota Denpasar. Responden yang tidak menggunakan APD meningkatkan risiko 
Arc. Com. Health • Agustus 2021

p-ISSN 2302-139X e-ISSN 2527-3620

Vol. 8 No. 2: 325 - 342

mengalami kejadian dermatitis kontak akibat kerja.

Tidak terdapat hubungan antara umur, tingkat pendidikan, dan penggunaan topi dengan kejadian dermatitis kontak akibat kerja pada pekerja pengangkut sampah DLHK Kota Denpasar.

\section{SARAN}

Bagi petugas pekerja pengangkut sampah untuk lebih menjaga dan meningkatkan higiene perorangan dan menggunakan alat pelindung diri yang lengkap seperti baju dan celana panjang, topi sepatu boot, sarung tangan untuk mencegah terjadinya kejadian dermatitis kontak akibat kerja.

Bagi DLHK Kota Denpasar agar lebih meningkatkan penyediaan sarana APD kepada para pekerja pengangkut sampah serta mengatur jam kerja dan shift kerja agar setiap pekerja memiliki waktu kerja yang merata serta tidak melebihi nilai ambang batas. Para pekerja perlu di sediakan hand sanitizer dan juga masker sebagai APD tambahan terlebih lagi saat ini sedang terjadi pandemic Covid 19 Selain itu DLHK Kota Denpasar dapat bekerja sama dengan Dinas Kesehatan dalam upaya memberikan penyuluhan kepada petugas pengangkut sampah tentang tindakan kebersihan diri dan penggunaan APD ketika bekerja.

$\begin{array}{rcr}\text { Bagi } & \text { peneliti } & \text { selanjutnya } \\ \text { disarankan } & \text { menetapkan } & \text { kejadian } \\ \text { dermatitis } & \text { kontak pada } & \text { pekerja }\end{array}$
pengangkut sampah berdasarkan diagnose dokter sehingga dapat mengetahui secara pasti jenis kejadian dermatitis kontak akibat kerja yang dialami oleh responden.

Meneliti lebih lanjut mengenai faktorfaktor yang memengaruhi kepatuhan responden dalam menggunakan APD serta meneliti lebih lanjut mengenai faktorfaktor yang memengaruhi penyediaan APD oleh pemberi kerja.

\section{UCAPAN TERIMA KASIH}

Terima kasih kepada Kepala Dinas Lingkungan Hidup dan Kebersihan Kota Denpasar khususya Kepala Bidang Pengelolaan Sampah dan Bahan Berbahaya Beracun (B3) DLHK Kota Denpasar yang telah membantu melancarkan penelitian dan membantu memudahkan penulis memperoleh data.

\section{DAFTAR PUSTAKA}

Aisyah, F. (2012). Hubungan Hygiene Perorangan dan Pemakaian Alat Pelindung Diri dengan Keluhan Gangguan Kulit Pada Pekerja Pengupas Udang di Kelurahan Pekan Labuhan Kecamatan Medan Labuhan Tahun 2012, 6.

Angriyasa, I. K. J., Mahayana, I. M. B., \& Hadi, M. C. (2018). Hubungan Pengetahuan Personal Hygiene dengan Gejala Penyakit Kulit Pada Pemulung di Tempat Pembuangan Akhir Sampah Suwung Denpasar Tahun 2018, 8(2), 51-58.

Ardiyanti, S. (2015). Faktor Resiko Terjadinya Penyakit Akibat Kerja Pada Petugas Pengangkut Sampah Di Kecamatan Semarang Utara Tahun 2015.

Azizah, F. N. (2018). Hubungan Higiene Perorangan Dan Penggunaan Alat Pelindung Diri Dengan Gangguan Kulit Pada Petugas Pengangkut 
Sampah Kota Tangerang Selatan Tahun 2018, 11, 126-140.

Butarbutar, M. R. J., Ashar, T., \& Santi, D. N. (2012). Hubungan Hygiene Perorangan dan Pemakaian Alat Pelindung Diri dengan Keluhan Gangguan Kulit dan Kecacingan pada Petugas Pengangkut Sampah Kota Pematang Siantar Tahun 2012.

Darung, M. C. (2018). Hubungan antara pengetahuan dan PHBS dengan kejadian tinea pedis pada pemulung Maria Chindyvita Darung, (1), 1-18.

Dewi, S. R., Tina, L., \& Nurzalmariah, O. S. (2016). Hubungan Personal Hygiene, Pengetahuan dan Pemakaian Sarung Tangan dengan Kejadian Penyakit Dermatitis Kontak pada Pemulung Sampah Dipta Puuwatu Kota Kendari Tahun 2016. https://doi.org/10.1017/CBO978110741 5324.004

Faridawati, Y. (2013). Hubungan Antara Personal Higiene Dan Karakteristik Individu Dengan Keluhan Gangguan Kulit Pada Pemulung (Laskar Mandiri) Di Kelurahan Sumur Batu Kecamatan Bantar Gebang Tahun 2013.

Girsang, M., \& Tobing, K. (2010). Karakteristik Demografis dan Hubungannya dengan Penyakit Tuberkulosis di Provinsi Jawa Tengah. Hiola, R. (2012). Hubungan Antara Kebersihan Perorangan dan Pemakaian Alat Pelindung Diri Dengan Kejadian Penyakit Kulit Pada Petugas Pengelola Sampah di Tempat Pembuangan Akhir (TPA) Tanjung Kramat.

Indrawan, I., Suwondo, A., \& Lestantyo, D. E-mail korespondensi: arya.utami@unud.ac.id
(2014). Faktor-Faktor Yang Berhubungan Dengan Kejadian Dermatitis Kontak Iritan Pada Pekerja Bagian Premix Di PT. X Cirebon. Jurnal Kesehatan Masyarakat (e-Journal), 2(2), 110-118.

Isro'in, L. (2012). Personal Hygiene Konsep, Proses, dan Aplikasi dalam Praktik Keperawatan.

Kemenkes RI. (2007). Laporan Nasional Riskesdas 2007. Kementerian Kesehatan Republik Indonesia, 1-384. https://doi.org/1 December 2013

Khoinur, H. F. (2019). Hubungan Penggunaan Alat Pelindung Diri Terhadap Penyakit Kulit (Dermatosis) pada Nelayan di Desa Bogak Kabupaten Batu Bara, 4(1), 75-84. https://doi.org/.1037//00332909.I26.1.78

Kushartanti. (2012). Beberapa Faktor yang Mempengaruhi Perilaku Cuci Tangan Pake Sabun di SDN 3 Brebes, (2), 1-13. Kusnin, R. M. (2015). Hubungan Antara Personal Hygiene dan Pemakaian Alat Pelindung Diri Dengan Kejadian Penyakit Kulit Pada Pemulung Di TPA Tanjung Rejo Kecamatan Jekulo Kabupaten Kudus.

Kusumaningrum, A., \& Widayati, R. (2017). Efektivitas Macadamia Oil 10\% Dalam Pelembab Pada Kulit Kering. Jurnal Kedokteran Diponegoro, 6(2), 347356.

Laila, F. (2015). Hubungan Antara Pemakaian Alat Pelindung Diri ( Apd ), Masa Kerja , Dan Personal Hygiene Dengan Kejadian Dermatosis Pada Pekerja Pengupas Singkong di UD. Gondosari Kabupaten Pati, 1-73.

Lestari, F., \& Utomo, H. S. (2007). Faktor- 
Arc. Com. Health • Agustus 2021 p-ISSN 2302-139X e-ISSN 2527-3620

Faktor Yang Berhubungan Dengan

Dermatitis Kontak Pada Pekerja Di Pt Inti Pantja Press Industri. Makara Kesehatan, 11(1), 61-68. https://doi.org/10.1252/kakoronbunsh u.16.56

Maharani, Krisnarto, E., \& Marfuati, N. (2016). Hubungan Penggunaan Sepatu Boot dengan Terjadinya Onikomikosis pada Petugas Pengangkut Sampah di TPA Jatibarang Kota Semarang, 2-3.

Mustikawati, I. S., Budiman, F., \& Rahmawati. (2012). Hubungan Perilaku Penggunaan Alat Pelindung Diri ( Apd ) Dengan Keluhan Gangguan Kulit di TPA Kedauang Wetan.

Peraturan Presiden Republik Indonesia Nomor 7 Tahun 2019 Tentang Penyakit Akibat Kerja.

Prayanti, N. M. V., \& Kartika, I. N. (2018). Analisis Pengaruh Program Bank Sampah Terhadap Pendapatan Nasabah Bank Sampah Di Kota Denpasar, 1256-1281.

Purba. (2016). Hubungan Personal Hygiene , Penggunaan Alat Pelindung Diri dan Karakterisitk Pekerja Petugas Pengangkut Sampah dengan Keluhan Gangguan Kulit di Kelurahan Petisah Tengah Tahun 2016.

Safriyanti, Hariati, \& Ibrahim, K. (2016). Hubungan Personal Hygiene, Lama Kontak, Dan Riwayat Penyakit Kulit Dengan Kejadian Dermatitis Kontak Pada Petani Rumput Laut Di Desa Akuni Kecamatan Tinanggea Kabupaten Konawe Selatan Tahun 2016, 1-10.

Sajida, A. (2012). Hubungan Personal Hygiene dan Sanitasi Lingkugan
Vol. 8 No. 2: 325 - 342

Dengan Keluhan Penyakit Kulit Di Kelurahan Denai Kecamatan Medan Denai Kota Medan Tahun 2012, (August), 32.

Salamah, A. N. (2012). Dermatitis Kontak Pada Pekerja Konstruksi PT. Waskita Karya Proyek World Class University di Universitas Indonesia Tahun 2012.

Saputra, I. K. D. A. (2016). Penyakit Kulit Akibat Kerja pada Pemulung di Tempat Pembuangan Akhir Suwung Denpasar Selatan Tahun 2016.

Srisantyorini, T., \& Cahyaningsih, N. F. (2019). Analisis Kejadian Penyakit Kulit pada Pemulung di Tempat Pengolahan Sampah Terpadu ( TPST ) Kelurahan Sumur Batu Kecamatan Bantar Gebang Kota Bekasi.

Suma'mur. (2009). Higene Perusahaan dan Keselamatan Kerja, 1-53.

Susanty, E. (2015). Hubungan Personal Hygiene dan Karakteristik Individu terhadap Kejadian Dermatitis pada Petani Rumput Laut di Dusun Puntondo Kabupaten Takalar. Acta Universitatis Agriculturae et Silviculturae Mendelianae Brunensis, 16(2), 39-55. https://doi.org/10.1377/hlthaff.2013.06 25

Trismariyani, D. M. (2018). Faktor Risiko Dermatosis Pada Petugas Pengolahan Sampah Terpadu (TPST) Dinas Lingkungan Hidup Kabupaten Jember.

Witasari, D., \& Sukanto, H. (2014). Dermatitis Kontak Akibat Kerja: Penelitian Retrospektif ( Occupational Contact Dermatitis: Retrospective Study ), 26(3), 161-167.

Zania, E., Junaid, \& Ainurlafliq. (2017). 
Faktor-Faktor yang Berhubungan dengan Kejadian Dermatitis Kontak Pada Nelayan di Kelurahan Induha
Kecamatan Latambaga Kabpaten Kolaka Tahun 2017, 3(3), 1-8. 